Stratton also acknowledges that "it's a new ball-game", pointing out that the companies set up to hunt for new genes "have budgets with an extra zero on the end compared to those of most academic groups".

Some researchers argue that patenting genes will slow down scientific progress, and that those seeking patent protection will delay publication. But others argue that communication could be eased by faster patenting procedures.

Skolnick hopes people will not prejudge Myriad on its licensing policy. "We want to collaborate, and we're not going to slit our throats by cutting everybody off or by charging exorbitant amounts," he says. "As we develop a policy, I'm sure we'll test the waters, and if we get whacked good and hard then we'll hopefully refine the policy."

But it is in the European Union (EU) that the outlook for gene patents remains cloudiest. The European Parliament is opposing parts of a European Commission directive that would standardize national laws on patenting life. In its current draft form, the directive rules that parts of the human body, including genes, cannot be patented when they remain in the body.

After the Council of Ministers decided this week not to accept amendments proposed by the parliament, representatives of the two sides will now have to meet to try to agree a single text. But, rather than adopt a directive that explicitly banned patenting genes, ministers could well abandon the whole draft.

Declan Butler \& Diane Gershon

\section{Court rules cell lines are protected by law}

Washington. In a precedent-setting decision, a court in Baltimore, Maryland, has required a researcher at the National Institutes of Health (NIH) in Bethesda, Maryland, to pay $\$ 5,000$ for deliberately destroying a cell line developed by co-workers in his laboratory.

After a five-day trial, Judge Peter Messitte ruled that Prince Kumar Arora, a researcher in the NIH's Laboratory of Neuroscience, destroyed cells developed by a colleague, Yochitatsu Sei, as part of an investigation of the impact of certain molecules on the brain.

Imposing both compensatory damages of $\$ 400$ and punitive damages of $\$ 5,000$, the court concluded that Arora had been motivated by jealousy. The ruling effectively enlarges the concept of 'conversion of property' to give protection to genetically engineered cell lines developed during the course of a research project.

The NIH, which participated as a civil party in the suit, had asked the court to accept the idea of 'conversion', reserved until now for circumstances in which one individual illegally appropriates the proceeds of property belonging to another. $\square$

\title{
EPA rebuffs challenge to its assessment of dioxin data
}

Washington. With its latest study of health risks from dioxins nearly complete, the US Environmental Protection Agency (EPA) last week went out on a limb to say that dioxins probably cause cancer in humans. But the agency says it still needs additional data before making this conclusion definitive; and the case may never be closed entirely.

EPA has released a "public review draft" of its three-year reassessment of dioxin risks, the most exhaustive scientific review of any family of compounds ever undertaken by the agency. As expected, the agency is sticking with its 1985 assessment that dioxins are a proven animal carcinogen and a likely human carcinogen, even in trace amounts.

In addition, the EPA draft says that dioxins may have other effects on health, including reproductive problems and suppression of the immune system, although it is not yet clear at what dosage those effects occur in humans.

The report will not be finalized until September 1995, following a four-month public comment period, and a review by EPA's Science Advisory Board early next year. Meanwhile, the agency is calling for additional data from scientists, industry, government agencies and any other groups that might have new information on dioxin.

The draft report points out that there are large gaps in researchers' understanding of dioxin sources and the levels at which it exists in the environment and in food, the principal route of human exposure. EPA estimates that 95 per cent of dioxins come from incinerators that burn medical and municipal waste, but says there may also be unknown sources.

EPA initiated the reassessment in 1991, after some scientists had begun to question whether the risks from dioxin had been overstated. Research showing that TCDD, the most toxic of the dioxins, had first to bind with a receptor protein before causing any harm to cells implied that there might be a threshold before the binding occurred below which dioxin was not a problem.

EPA's models assume there is no such threshold, and therefore no 'safe' level of dioxin. Most European countries, as well as Canada, think this model is unrealistic, and have set their dioxin exposure limits much higher. But, after three years of reviewing the data, and conducting dose-response studies in its own laboratories and others, EPA still has not identified a threshold amount of dioxin that triggers a response.

Other incriminating studies were published during the three-year reassessment, including stronger epidemiological data link- ing dioxin exposure to excessive cancer cases in Seveso, Italy, the site of an explosion in 1976 at a chemical plant. Other recent research has tied dioxin to endometriosis in rhesus monkeys and the suppression of the immune system in mice.

Much of the work for EPA has been spent staying abreast of these new findings. Lynn Goldman, the agency's assistant administrator for pesticides and toxics, says, "Every week there are new studies that are published. It's a challenge to keep up with the data."

Mindful of past criticism of its risk analysis methods, EPA has gone to great lengths during the dioxin reassessment to include participation of external scientists. Earlier drafts of the study went through three separate peer reviews, as well as a review by scientists in other federal agencies.

The authors or co-authors of several chapters were in fact scientists outside EPA. "This has been a new approach for the agency, to really make this an inclusive process," says Linda Birnbaum, director of the agency's Environmental Toxicology Division in Research Triangle Park, North Carolina.

Birnbaum says that providing definitive proof that dioxin causes cancer in humans could be a very tough proposition. "We need unequivocal human data, and that's very difficult to get."

One of the problems with dioxin epidemiology, says Birnbaum, is that these chemicals do not cause a unique kind of tumour that is readily identifiable. As a result, dioxin effects would not stand out from those of any other carcinogen. "We're looking at relatively small incidences over very large background incidences," she says.

Despite its contention that even minute amounts of dioxin pose a health risk, EPA is keen to avoid appearing alarmist. There is relatively little dioxin in the environment only 30 pounds in the entire United States, by one estimate. As a result, says Goldman, even though dioxins accumulate in fatty tissue and show up in beef, dairy products and fish, the amounts are so small that the benefits of a healthy diet far outweigh the risks from dioxin.

Indeed, EPA says it will not take any new regulatory action until the results of the reassessment have been finalized next year. Considering that it has already proposed new rules cutting dioxin emissions from pulp and paper mills and municipal waste incinerators, and that it expects to propose new rules on medical waste incinerators next February, there may not be much dioxin around by the time the last bit of scientific evidence is in. 